\title{
2 \\ EU Cohesion Policy and Microfinance
}

Giorgio Centurelli, Pasqualina Porretta and Fabrizio Santoboni

\subsection{Cohesion policy, EU structural funds and financial engineering instruments: regulatory framework and operational features under the programming periods 2000-2006 and 2007-2013}

The aim of ensuring a balanced development of the territory of the European Union as well as equal social and economic opportunities to all individuals in the EU member states led European Union institutions to activate a number of financial instruments that may allow reducing the current structural economic gaps between different regions in Europe and establishing a regional development policy based on the concepts of economic, social solidarity and cohesion. ${ }^{1}$

The regional development policy, already introduced in the early 1970s, albeit in an embryonic state, finds its milestones in the Single European Act (SEA) of 1986 and the subsequent Treaty of Maastricht on the European Union in 1992. ${ }^{2}$

Those were the years that gave birth to the cohesion policy and its main financial arm (ERDF, European Regional Development Fund); in addition, a careful and rational planning process started to gradually emerge. This is the origin of the EU programming cycles: multiyear plans for regional policies, initially of variable duration (1989-1993, 1994-1999), and then, from 2000 onwards, established in seven-year cycles (2000-2006, 2007-2013 and now 2014-2020).

The evolution of the EU structural funds programming has been accompanied by the introduction of increasingly detailed and stringent regulations. The regulatory framework has obviously covered also the financial engineering instruments, which while governed by a few provisions in the programming period $2000-2006,{ }^{3}$ are now regarded as 
a strategic tool within the programming period 2014-2020 and, as such, governed by specific regulations, as we will see later.

\subsubsection{The regulatory framework in the programming period 2000-2006: first implementing provisions in regulation (EC) no. $448 / 2004$}

As mentioned above, the regulatory framework of the programming period 2000-2006 contained the first framework laying down detailed rules to define the financial engineering instruments.

Regulation (EC) no. 1260/1999 of the EU council of 21 June $1999^{4}$ laying down "General provisions on the structural funds" 5 made no mention whatsoever of the financial instruments, and their regulatory framework could be only found in two rules (no. 8, Venture capital and loan funds; no. 9, Guarantee funds) of Annex no. 1, "Eligibility rules", of EC regulation no. 1685/2000 of 28 July 2000 laying down a number of implementing rules and then the following EC regulation no. 448/2004 of 10 March $2004 .^{6}$

In particular, the regulation concerning programming period 20002006, defined the "venture capital funds and loan funds as investment vehicles established specifically to provide equity or other forms of risk capital (including loans) to small and medium-sized enterprises, except those enterprises in difficulty". In fact, the structural funds' participation in funds may be accompanied by co-investments or guarantees from other community financing instruments.

The legislation included some provisions that would later be reinforced in subsequent planning cycles, such as the mandatory introduction of a prudent "business plan" on which the "guarantee fund" had to be based. The business plan had to be carefully appraised and its implementation monitored by or under the responsibility of the managing authority. In addition, the text added that the fund should be set up as an independent legal entity governed by agreements between the shareholders or as a separate block of finance within an existing financial institution. $^{7}$

The fund management costs could not exceed 2 per cent of the paid-up capital on a yearly average for the duration of the assistance programme unless, after a competitive tender, a higher percentage proves necessary. Finally, the regulation emphasised that, at the time of closure of the operation, the eligible expenditure of the fund should be the amount of paid-up capital of the fund necessary, on the basis of an independent audit, to cover the guarantees provided, including the management costs incurred. It is clear here that the legislation, albeit very basic, primarily 
referred to measures strictly within the scope of the ERDF and not to the European Social Fund (ESF), that is, measures related to entrepreneurial development and the competitiveness of enterprises rather than initiatives aiming at promoting social inclusion and employment (ESF area of competence), as previously explained (see Chapter 1).

\subsubsection{The regulatory framework of the programming period 2007- 2013: specific features of the financial engineering instruments}

Within the programming period 2007-2013, the financial engineering instruments start to play a central role in the regulatory framework and implementation plans of the European Commission.

The renewed strategic importance of such instruments lays the foundations for their strong development both within the ERDF (with a primary focus on innovation and information-based economy) and the ESF through specific microcredit programmes targeting social inclusion and the creation of jobs.

The general regulation (EC) no. 1083/2006 and implementing provisions in regulation (EC) no. 1828/2006

As already highlighted, the financial engineering instruments are governed not just by EC regulation no. $1828 / 2006^{8}$ setting out rules for the implementation of council regulation (EC) no. 1083/2006, but also by EC regulation no. 1083/2006 ${ }^{9}$ itself, laying down general provisions on the ERDF, as well as by the structural funds specific regulations (with regard to the ERDF, see arts 3-6 of EC regulation no. 1080/2006, ${ }^{10}$ and for the ESF see art. 11 of EC regulation no. 1081/2006) ${ }^{11}$ and start enjoying a systemic and satisfactory definition. In particular, EC regulation no. 1083/2006 dedicated an entire section (no. 4) to the financial engineering instruments. Art. 44 explicitly stated that, within a given operational programme, the structural funds could finance:

(a) financial engineering instruments for enterprises, especially small and medium-sized enterprises, such as venture capital funds, guarantee funds and loan funds;

(b) urban development funds, that is, funds investing in public-private partnerships and other projects included in an integrated plan for sustainable urban development;

(c) any loans or guarantees for repayable investments from funds or other incentive schemes providing loans, guarantees for repayable investments or similar instruments for energy efficiency and the use of renewable energy sources in housing, including existing housing. 
Always with regard to the financial instruments, to the above must be added also the exception constituted by the creation of the funds dedicated to the EU reporting process. As is known, all statements of expenditure submitted to the European Commission shall include the total amount of eligible expenditure actually incurred by the beneficiaries, that is, the amounts supported by receipted invoices. The process is, therefore, dependent on the expenditure actually met, which, when duly supported by the accounting documents and complying with the regulations indicated in the documents illustrating the management and control systems adopted by each operational programme, are then certified to the European Commission in order to contribute to the achievement of the annual EU spending targets and avoid the penalty of the automatic decommissioning of resources at the end of the year. There are some exceptions to the above principle though: state aid ${ }^{12}$ within certain limits, the simplified costs, as firstly introduced by the programming period 2007-2013 and, with regard to the financial engineering instruments, the total expenditure paid in establishing or contributing to funds under art. 44 of EC regulation no. 1083/2006 or holding funds or the expenditure paid to invest in the latter (see art. 78, paragraph 6 , of EC regulation no. 1083/2006).

In other words, the amount transferred to the managing authority to create, for instance, a guarantee or revolving fund, was already regarded as certifiable expenditure, unlike the general rule imposed to wait for the transformation of the sums transferred into actual expenditure.

A broader scope combined with the relative appeal in terms of expenditure certification resulted in a relative increase in the use of such instruments already during the programming period 2007-2013, up to representing approximately 5 per cent ${ }^{13}$ of the ERDF total resources in 2012 and reaching a considerable share also within the ESF. In particular, according to communication COM (2011) no. 662, within the programming cycle 2007-2013, nearly all member states implement a range of equity and/or debt (loan and guarantee) instruments, either directly by contributing resources from an operational programme to a venture capital fund, loan or guarantee fund or through holding funds set up to invest in several funds. ${ }^{14}$

In many cases, instruments are implemented through investments into holding funds. Under the JESSICA initiative (Joint European Support for Sustainable Investment in City Areas), holding funds are implemented through the EIB. Under the JEREMIE initiative (Joint European Resources for Micro to Medium-Sized Enterprises), holding funds are generally implemented through the EIF or a range of national 
or regional institutions. The importance of the financial instruments over time, in particular at the end of the first three years of planning, made it necessary to strengthen also their supervisory framework, and this is why in 2011, following the amendment to art. 67 of the general regulation by EU regulation no. 1310/2011 of the European Parliament and Council of 13 December 2011, ${ }^{15}$ the latter established the obligation to give notice of the implementation of the financial instruments in the annual reports as well as in the final implementation reports. With regard to the financial engineering instruments, EC regulation no. 1828/2006, section no. 8 (arts 43-46), setting out rules for the implementation of council regulation (EC) 1083/2006, introduced also a number operational provisions, which clarified and improved the regulatory framework already existing within the programming period 2000-2006, in particular with respect to investment plan and management costs. Art. 43 , in fact, established that "The terms and conditions for contributions from operational programmes to financial engineering instruments shall be set out in a funding agreement, to be concluded between the duly mandated representative of the financial engineering instrument and the Member State or the managing authority". The funding agreements were to include at least the following:

- Strategy and investment plan;

- The by-laws of the financial engineering instrument;

- The policy of the financial engineering instrument concerning exit from investments in urban projects or enterprises;

- The winding-up provisions of the financial engineering instruments, including the reutilisation of resources returned to the financial engineering instrument from investment or left over after all guarantees have been honoured, attributable to the contribution from the operational programme.

With regard to the management costs, the following limits were established:

(a) 2 per cent of the capital contributed from the operational programme to the holding funds, or the capital contributed from the operational programme or the holding fund to the guarantee funds;

(b) 3 per cent of the capital contributed from the operational programme or the holding fund to the financial engineering instrument in all other cases, with the exception of microcredit instruments directed at microenterprises; 
(c) 4 per cent of the capital contributed from the operational programme or the holding fund to microcredit instruments directed at microenterprises.

The above limits could be exceeded though any time a higher percentage was proved necessary after a competitive tender.

\section{The Coordination Committee of the Funds (COCOF) notes}

In the programming period 2007-2013, in order to offer specific guidance on the issues related to the implementation of the regulations governing the structural funds and the Cohesion Fund (pursuant to art. 103 of regulation no. 1083/2006), the EU provided for the creation of a Coordination Committee of the Funds (COCOF) as a permanent committee operating within the European Commission.

This committee, which used to convene once a month, was chaired by the European Commission and would produce guidelines, called "notes", in the EU legislative jargon. As for the financial engineering instruments, the committee issued notes COCOF/07/0018/01 and COCOF/08/0002/03 and, finally, COCOF 10/0014/04 of 21 February 2011, amended by the note under the title "Guidance note on financial engineering instruments under art. 44 of Council Regulation (EC) No. 1083/2006" of 14 December 2011. ${ }^{16}$

Note COCOF 10/0014/04 aimed to provide some clarifications on issues related to the creation and implementation of the financial engineering instruments, in accordance with art. 44 of EC regulation no. 1083/2006, but also technical information and good practices.

The content of the aforementioned note is quite complex and addresses a number of specific issues concerning management and controls that were explicitly mentioned also by the EC decision of 20 March 2013 on the approval of guidelines on the closure of the operating programmes adopted for assistance from the European Regional Development Fund, the Social European Fund and the Cohesion Fund (2007-2013). In particular, the note anticipated the still-much-debated issue of the closure of the financial instruments. As previously mentioned, the expenditure related to this type of intervention can be immediately certified to the European Commission and contribute to achieving the annual expenditure targets, it being sufficient the establishment and transfer of the relevant amounts to the managing authority. At the partial or total closure of the programme, that is, at the end of eligible expenditure, which for the programming period 2007-2013 was established on 31 December 2015 , in compliance with art. 78 , paragraph 6 , of the general regulation, 
eligible expenditure, with regard to financial engineering instruments, that can be included in the final statement of expenditure shall correspond to the sum of the following amounts:

- Any payments from urban development funds for investment in public-private partnerships or other projects included in an integrated plan for urban development.

- Any payment for investments in enterprises from financial engineering instruments directed at enterprises.

- Any guarantees provided, including amounts committed as guarantees by guarantee funds.

- Any loans or guarantees for repayable investments from funds or other incentive schemes providing loans, guarantees for repayable investments, or equivalent instruments, for energy efficiency and use of renewable energy in buildings, including in existing housing.

- Eligible management costs or fees.

For the expenditure to be considered eligible at the closure of the programme, it is not necessary that the final recipient completed the implementation of the activity supported by the financial engineering instrument, which can, therefore, continue also after 31 December 2015.

The exception to the general rule of the financial instruments under implementation is, therefore, overcome upon closure of the programme and the lack of implementation of the funds in the final statement of expenditure translates into the write-off of the expenditure not incurred.

The programming period 2007-2013, despite the relevant production of secondary regulatory legislation on eligibility issues related to financial engineering instruments, left open some interpretative doubts that resulted in several requests for opinion, which were collected by the European Commission during the meetings with the member states for the closure of the programmes in the second quarter of 2014 and are currently being assessed to provide further guidance in the last quarter of 2014.

\subsection{Financial instruments in the cohesion policy 2014-2020: regulatory framework}

With its communication of 3 March 2010, the European Commission launched the new ten-year political strategy Europe 2020 (see also Chapter 1) with the aim not only to overcome the economic crisis which continues to affect several EU countries but also to fill in the gaps of the 
European development model and create the conditions to achieve a smart, sustainable and inclusive economic growth. The new programming period obviously includes also the financial engineering instruments, which are regarded as the main tool to deploy the resources of the cohesion policy aimed at achieving the proposed targets by 2020 . The financial instruments, in fact, provide a targeted support for investments in projects that display potential economic viability and, besides the clear advantages related to the long-term reutilisation of the funds, they provide additional investments through public-private partnerships, thus correcting some imbalances of the market. Moreover, given the increasingly difficult economic crisis and scarcity of public resources, these instruments may have an even greater impact on the cohesion policy throughout the programming period 20142020, representing a more efficient and sustainable alternative aimed at integrating traditional grant-based forms of assistance. The previous considerations are justified in light of the relevant regulatory changes on financial engineering instruments introduced by the new EU legislation related to the programming cycle 2014-2020. Awaiting the adoption of secondary regulations, these instruments are now entirely governed by the Title IV (arts 37-46) of EU regulation no. 1303/2013 of the European Parliament and Council of 17 December 2013.

While we postpone a detailed analysis to the next paragraphs, in order to encourage and increase the use of such financial instruments in the cohesion policy, the new regulatory system

- introduces a greater flexibility;

- establishes a stable framework for their implementation based on a number of clear and detailed provisions as well as on existing guidelines and empiric experience in the business practice;

- promotes integration with other forms of assistance, such as subsidies;

- ensures compatibility with other EU financial instruments with a series of provisions on direct management.

As for the types of financial instruments to be activated with the resources from the structural funds, the European Commission lays out only some recommendations.

In particular, the aforementioned communication COM (2011) no. $6622^{17}$ provides for three options:

1. Member states continue creating tailor-made instruments under shared management principles, aligned with some common rules 
inspired by the EU equity and debt platforms under development for the EU instruments.

2. Creation of "off-the-shelf instruments" under shared management principles which would facilitate the set-up of instruments for member states as well as ensure compatibility with the EU-level instruments.

3. Member states would be encouraged to invest part of their structural funds in compartments of EU level instruments "ring-fenced" for investments in regions and policy areas covered by operational programmes from which structural funds resources are contributed ("joint instruments").

\subsubsection{The main amendments compared to previous programming periods}

Unlike those related to the programming period 2007-2013, the regulations governing the financial instruments for the programming period 2014-2020 are not mandatory with regard to the sectors, beneficiaries, types of projects and activities to be funded. Member states and managing authorities can, therefore, use such instruments for all the 11 thematic objectives under the operational programmes and all structural funds, where appropriate, for reasons of efficiency and effectiveness. Besides the extension of the scope of the financial engineering instruments, the new regulatory framework introduces some relevant changes that could be summarily referred to the following areas: ex ante assessment; reporting; monitoring.

Firstly, art. 37 of EU general regulation no. $1303 / 2013^{18}$ for the first time introduces the obligation, any time a financial instrument is activated, to prepare a specific ex ante assessment which may establish evidence of market failures and suboptimal investment situations, the estimated level and scope of public investment needs, the estimate of private resources to be potentially raised by the financial instrument and the added value of the financial instruments that are being considered for support. In addition, the ex ante assessment, which may also be reviewed and updated as required during the implementation of any financial instruments, must represent their added value as well as the consistency with other forms of public intervention addressing the same market, including lessons learnt from similar instruments and ex ante assessments carried out by member states in the past and how such lessons will be applied in the future. Moreover, the ex ante assessment may be performed in stages, but it must be, in any event, completed before the managing authorities decide to make programme contributions to a financial instrument and must also be submitted to the 
monitoring committee for information purposes. The summary findings and results of ex ante assessments are published within three months of their date of finalisation. With regard to reporting, the main innovation compared to the previous framework is represented by the overcoming of the equivalence between the establishment of the funds and the certification of expenditure, which, in the programming period 2007-2013, had led the financial instruments at issue to assume a leading role in the acceleration of public spending.

In this sense, art. 41 of EU general regulation no. 1303/2013 introduces phased applications for interim payments paid to the financial instrument during the eligibility period. In particular, the amount of the programme contributions paid to the financial instrument included in each application for interim payment submitted during the eligibility period (more correctly, for the revolving funds and the guarantee funds, upon the transfer of the sums to the managing authority) cannot exceed 25 per cent of the total amount of programme contributions committed to the financial instruments under the relevant funding agreements.

Subsequent payments, always within the maximum allowed limit of 25 per cent, may be included in applications for interim payment, that is, certified to the European Commission, in compliance with the following provisions:

- For the second application for interim payment, when at least 60 per cent of the amount included in the first application for interim payments has been spent as eligible expenditure within the meaning of points (a), (b) and (d) of art. 42 of EU general regulation no. 1303/2013.

- For the third and subsequent applications for interim payment, when at least 85 per cent of the amounts included in the previous applications for interim payments have been spent as eligible expenditure within the meaning of points (a), (b) and (d) of art. 42 of EU general regulation no. 1303/2013.

With regard to the financial instruments, the following are considered eligible expenditure of the financial instrument within the meaning of the above-mentioned minimum levels (see paragraph 1, points (a), (b) and (d) of art. 42 of EU general regulation no. 1303/2013):

- Payments to final recipients and, in the event of financial instruments combined with other forms of assistance under a single programme, payments to the benefit of final recipients. 
- Resources committed for guarantee contracts, whether outstanding or already come to maturity.

- Reimbursement of management costs incurred or payment of management fees of the financial instrument.

Finally, as for the monitoring of the financial instruments, art. 46 of EU general regulation no. 1303/2013 provides that the new level of monitoring should not be limited to the introduction of a specific section in the annual and final implementation report (which are to replace the progress reports of the programming period 2007-2013) but imposes the obligation to send to the commission a specific report covering the operations comprising financial instruments as an annex to the annual implementation report.

Table $2.1^{19}$ below shows a summary of the specific differences between the programming periods 2007-2013 and 2014-2020 with regard to the financial engineering instruments (figures are valid both for ERDF and ESF).

\subsection{The control system}

One of the key factors of the EU cohesion policy spending is represented by the decentralised management system. Programmes are managed at regional and local level, so that the projects selected are better attuned to the local specific requirements. Member states and regions take the lead role in deciding how money should be used and bearing the responsibility for managing it properly. Within the member states, hundreds of organisations are involved in managing the different parts of the operational programmes; likewise, hundreds of thousands of beneficiaries implement individual projects. Such a system of decentralised government is prone to high inherent risks, due to the great number of organisations involved in the supply chain. ${ }^{20}$ The European Commission has supervisory role in ensuring that expenditure is in line with the agreed strategic priorities and financial rules; it is accountable under the EU treaty for the proper implementation of the budget. Two of its departments are mainly responsible for overseeing the cohesion policy spending; namely, the Directorates General for Regional Policy and for Employment, Social Affairs and Equal Opportunities. The objectives and priorities for the use of funds are laid down in individual operational programmes at national or regional level, negotiated between the European Commission and each member state and formally approved by the commission. The programme authorities select the projects to attain objectives set and to 


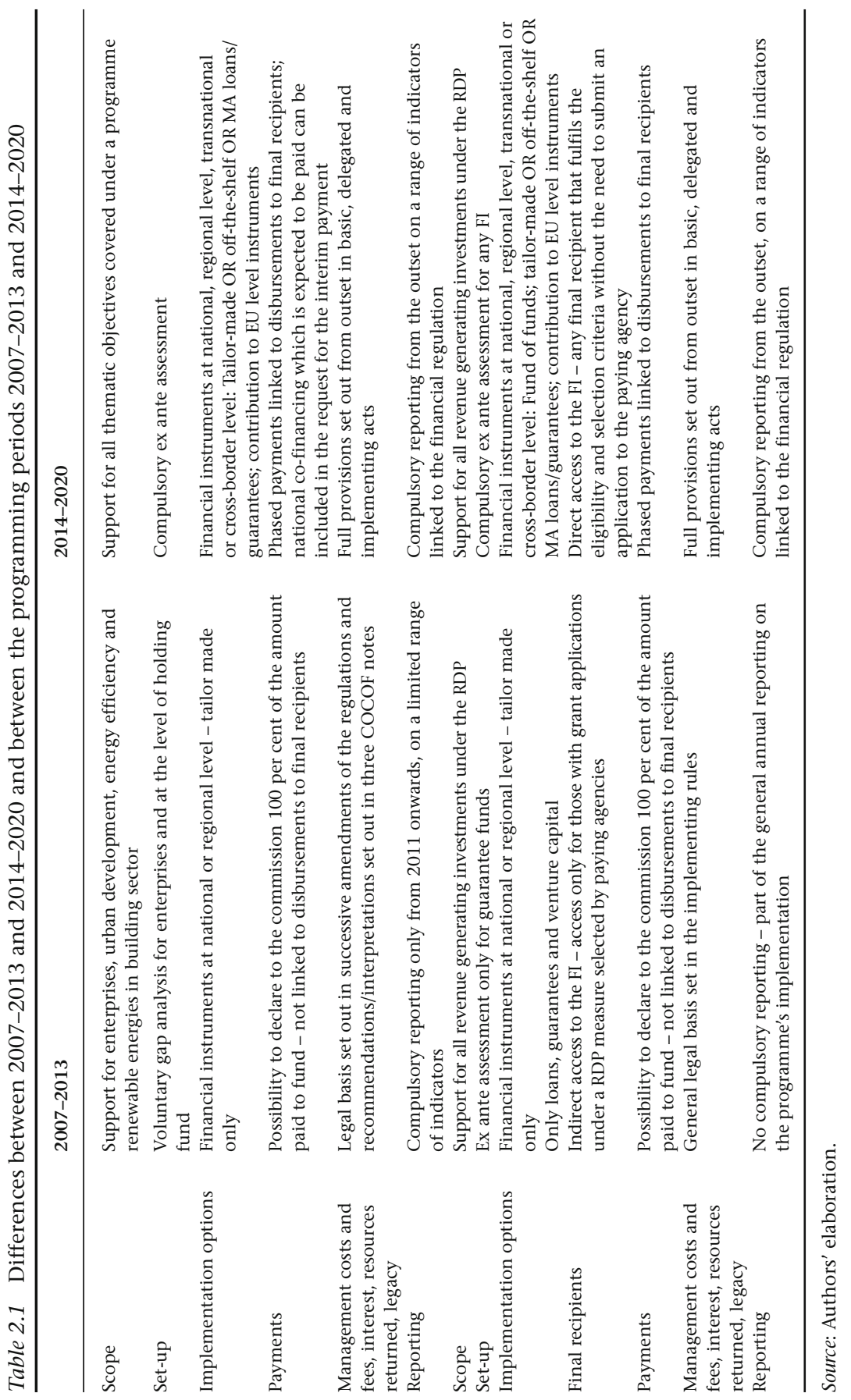


which the funds contribute. Throughout the period, the member state regularly declares the programme expenditure to the commission, and the commission later reimburses the agreed EU contribution. As previously examined, the beneficiaries have until the end of 2015 to complete projects and present the expenditure. The programme authorities then present the final expenditure claim and the programme is closed with a final payment to the member state. ${ }^{21}$ The funding of projects under an operational programme, as seen before, is subject to certain terms and conditions, laid down partly at EU and partly at member state level. These rules are established to ensure value for money, proper management of programmes and consistency with community policies.

These rules set out criteria for selecting the projects, assessment of cost benefits and earnings potential of the projects, competitive tendering, economic, social and environmental impact assessment and compliance with the EU legislation on state aid, if applicable. Moreover, the legislation imposes an indication of the location and type of the activities co-financed, the period during which the expenditure can be incurred, the minimum proportion of spending that is required on projects serving EU priorities such as innovation, job creation and environment, cost categories, restricted/excluded activities and, finally, the retention of supporting documents over minimum periods for audit and publicity purposes. $^{22}$

Under the decentralised and shared management system, the member states have primary responsibility for the control of programme expenditure, while the European Commission performs a supervisory role over the national systems. The dissemination of information among all subjects involved is another key element to implement a proper management and control system, as it helps prevent problems and encourage compliance. A multilevel control system is put in place: it is integrated on the basis of clearly defined responsibilities for the various actors, established standards for the work required and reporting systems and feedback mechanisms so that each level of control builds on the preceding one, with a view to reducing the burden, in particular the beneficiaries. The different levels of control must be independent from one another in order to perform their functions properly. In the member states there are three levels of control, and the corresponding whose bodies in each programme are as follows (Figure 2.1):

- The managing authority: represents the first level of control and has the key responsibility for making sure that the programme is effectively and correctly implemented. It must ensure that the operations 


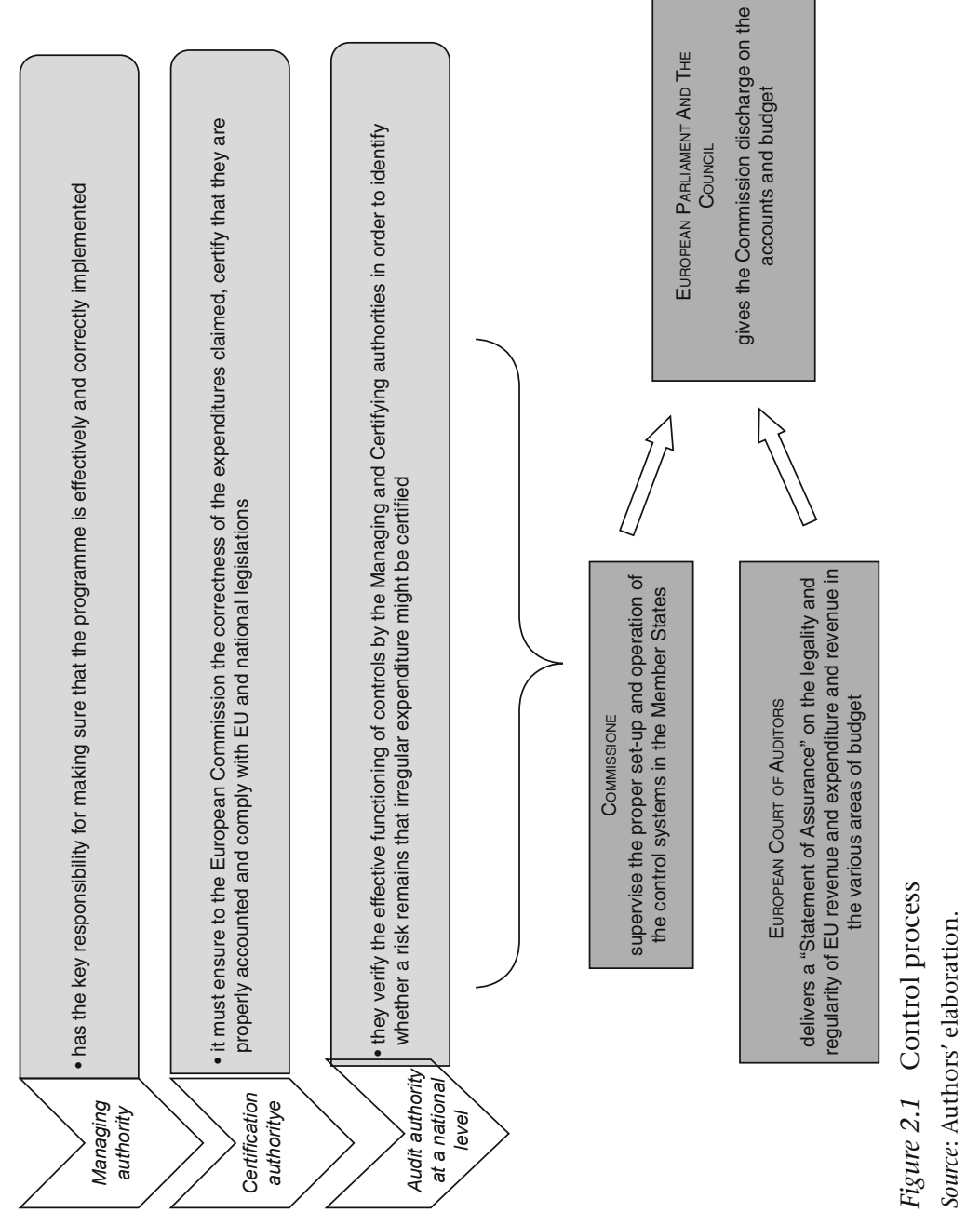


selected for the programme comply with the criteria established by the European Commission; it must advise the beneficiaries on what they have to do to meet the terms and conditions of funding; it must put in place and manage internal controls to check that the expenditure presented by the beneficiaries is regular. In addition, it must correct irregular expenditure found by withdrawing it from payment claims and recovering any grant already paid from the beneficiaries; it must monitor the implementation of the programme and send the commission annual reports on performance, which are discussed with the commission at annual meetings, and a final report summarising the implementation of the entire programme. ${ }^{23}$ The control of the managing authority may take the form of on-the-spot visits, desk checks on documents such as lists of invoices or reports used in the programme, interviews with the staff and examination of accounts and documentary records relating to tendering procedures.

- The certification authority: it must ensure to the European Commission the correctness of the expenditures claimed, certify that they are properly accounted for and comply with EU and national legislations. This authority receives the statements of expenditure from the managing authority before they are included in the request for payment to be sent to the commission. ${ }^{24}$

- The audit authority at a national level: they verify the effective functioning of controls by the managing and certifying authorities in order to identify whether a risk remains that irregular expenditure might be certified. Accordingly, they provide constant feedback as to the effective functioning of the management and control systems. Audits by EU bodies examine the overall functioning of the national control systems. Audits, however, cannot make up for ineffective first-level controls or lack of checking before certification of expenditure. ${ }^{25}$ The audit authorities in the member states have a key function in building up assurance in the system through the performance of the important responsibilities imposed by the regulations at the beginning of the period, during implementation and at closure.

At EU level, the role of the commission is to supervise the proper set-up and operation of the control systems in the member states by means of

- the compliance assessment procedure, approval of audit strategies and scrutiny of annual control reports and audit opinions;

- carrying out audits on the member states to gain assurance that the systems are working effectively; the EU Commission focuses on the 
reliability of the work of the audit authorities to provide this assurance through their annual control reports and audit opinions;

- monitoring information reported by member states on irregularities and recoveries of unduly paid funds;

- providing formal guidance to establish benchmarks and spread good practices; regulatory and control issues are discussed in the management committee composed of representatives of the European Commission and the member states (the Coordination Committee of the Funds, COCOF), in the technical working group of the ESF Advisory Committee and in technical meetings with the audit authorities;

- checking at the programme closure that the funding for the programme is properly justified. ${ }^{26}$

In addition, once a year the European Court of Auditors delivers a "statement of assurance" on the legality and regularity of EU revenue and expenditure and revenue in the various areas of budget. The assessments are based on audits carried out by the court in the member states and the commission, including a statistical sampling of 180 projects of member states. ${ }^{27}$

Finally, the European Parliament and the Council scrutinise the use of EU funds in the annual discharge procedure, which lasts from November to April, at the end of which the parliament gives the commission discharge on the accounts and budget. ${ }^{28}$

Assurance on the effectiveness of the control systems in preventing, detecting and correcting irregularities is built up throughout the whole programming period. In the negotiations on the operational programmes, the European Commission ensures that programme authorities are properly designated, and any problems found with the systems in previous period are adequately addressed. After programme approval, the compliance assessment procedure gives assurance on the satisfactory set-up of monitoring systems before any expenditure is reimbursed. Within 12 months from programme approval, a national audit body - often the audit authority - has to issue a certificate of compliance with regard to the internal control systems for the programme. The European Commission looks at the compliance assessment report and opinion to make sure it is consistent and reliable. Only after any necessary corrective measures have been taken and the commission is satisfied that the control system fully meets the regulatory requirements will it start to reimburse expenditure for the programme. At the beginning of the programme period, the commission also examines and approves the audit strategy submitted by the audit authority within nine months of programme adoption. ${ }^{29}$ As previously mentioned, the European 


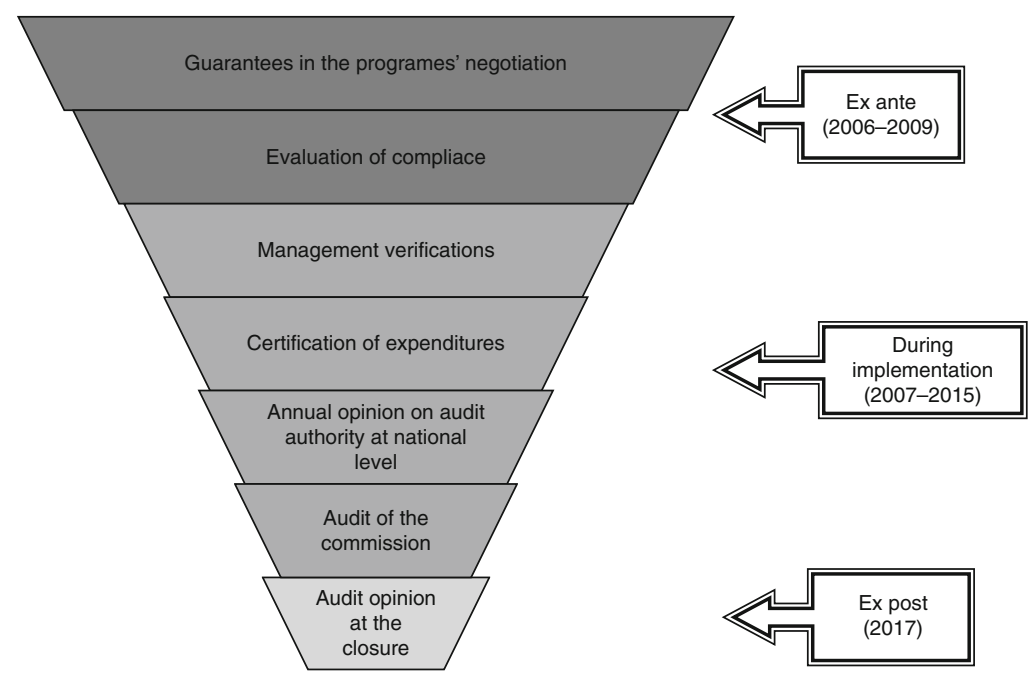

Figure 2.2 The monitoring process: phases

Source: Authors' elaboration on EU, "The Control System for cohesion policy", 2009.

Commission must examine also the reports prepared by the certification and audit authorities during the programming period.

Finally, at the end of the programme period, the audit authority issues an opinion on the accuracy and compliance with the rules of the expenditure declared from the programme in the final statement of expenditure; in addition, in its closure report, the audit authority gives details of the actions taken to improve systems and correct any irregular expenditure. The European Commission carefully scrutinises all closure declarations and, if needed, asks for more information or the performance of more audit work.

Figure 2.2 summarises the monitoring phases in the programming process. It is necessary to point out that the correction of any discrepancies lies in the responsibility of the member states, which must inform, every three months, the European Anti-Fraud Office of all irregularities ${ }^{30}$ related to EU funds exceeding €10,000.

\subsection{Structural funds and microfinance}

The European structural funds can be an effective mechanism to provide access to finance for small and microenterprises. As confirmed by a study carried out by the European Microfinance Network, ${ }^{31}$ microfinance is 
a financial instrument which can be supported by at least two structural funds: the European Social Fund (ESF) and the European Regional Development Fund (ERDF).

Since several years ago, at least at EU level, microfinance has gained growing recognition, as it represents a cost-effective tool for social inclusion on the one hand and for regional economic growth on the other. Supporting the setting up or developing of a microbusiness costs only a fraction of unemployment and health benefits paid out and activates excluded people's potential to become again active members of their communities. In the national action plans for social inclusion (NAPs), ${ }^{32}$ however, microfinance is most often not mentioned at all. If it is, it is not translated into the EFS operational programmes. The ERDF operational programmes instead tend to focus on funding for SMEs. During periods of crisis, national and regional policies tend to give priority to employment rather than self-employment initiatives; they tend to prefer small-, medium- and large-sized companies to microenterprises. Especially in the current crisis context, public policies specifically focus on requalification, training and advice for (former) employees of large enterprises rather than on establishing and developing microbusiness. It is therefore necessary to systematically integrate microfinance as a basic social and financial service into the national action plans and the structural funds' operational programmes. Moreover, microfinance, self-employment and microentrepreneurship should become policy priorities in the field of social exclusion and economic growth.

Microentrepreneurship and self-employment have proven a way to activate the labour market. Some individuals, in particular ESF beneficiaries (unemployed, immigrants, women, people 50 and up, young people), have a hard time finding a job but would be very good entrepreneurs. Supporting them in the creation of businesses is not just a way to save on unemployment or welfare benefits. In this sense, according to the Europe 2020 strategy, entrepreneurship is a key element to achieve smart, sustainable and inclusive growth. As mentioned in Chapter 1, the EC, therefore, encourages the member states to implement measures to promote entrepreneurship and self-employment initiatives by facilitating access to finance. Several programmes are available at EU level to support access to finance for small enterprises, such as CIP and JEREMIE, in addition to other programmes specifically designed for microfinance, such as JASMINE (Joint Action to Support Microfinance Institutions), EPPA (European Parliament Preparatory Action) and PROGRESS Microfinance (Programme for Employment and Social Solidarity). In 
addition to the above initiatives aimed at facilitating inclusion in the labour market, the EU has provided a specific form of support, both at regional and/or national level, represented by the use of financial engineering instruments under the structural funds (ESF and ERDF), both through direct grants and the JEREMIE programme. If on the one hand the ERDF resources are mainly used to support enterprises (mostly SMEs), urban development, energy efficiency and the use of renewable energy sources, on the other hand the ESF is used to promote self-employment, microenterprises and the creation of start-ups. ${ }^{33}$

More generally, the ESF aims to increase employment, promote entrepreneurship and improve social inclusion by favouring equal opportunities and non-discrimination as well as ensuring mobility and permanent education in Europe, in light with the Lisbon strategy and the integrated guidelines for economic growth and job creation.

\subsection{Implementing a microfinance programme through the structural funds}

Within the decision-making process for the structural funds, the managing authorities are invited to submit their national reform programmes (NRP) ${ }^{34}$ in the month of April every year, while they must also publish the National Strategic Reference Frameworks (NSRF) and the relevant operational programmes (OPs) in the first year of the programming period. The member states must use these documents to explain how they intend to integrate the EU objectives and priority guidelines in their respective national policies. The national reform programmes (NRP) are an important tool to implement the Europe 2020 strategy and monitor the expected results.

In several EU countries and regions, the managing authorities have already put in place microcredit programmes and schemes in accordance with the ESF operational programmes.

In Sardinia, the Fondo Microcredito (Microcredit Fund) was established in December 2009 and provided with a budget allocation of $€ 30$ million by the ESF, ${ }^{35}$ subsequently increased by $€ 20$ million. The programme's objective is to improve access to the labour market, create jobs and support SMEs and self-employment initiatives. This fund was created as the economic study highlighted critical unemployment levels, especially among women, and a tighter access to credit than in other regions in Italy. Moreover, numerous pilot projects had previously shown a strong demand for microcredit. Under this programme, loans up to $€ 25,000$ are granted to enterprises (not to single individuals) in 
different priority areas, such as retail, manufacturing business, social and personal services, tourism and ICT.

The correct management of the financial instruments co-funded by the EU structural funds lie in the responsibility of the managing authorities. The latter are active at national or regional level; they can be, for instance, the Ministry of Labour or a regional government body. When a microfinance programme is activated, several ministries can work in collaboration with the managing authority. Each ministry is vested with specific and clear responsibilities and carries out its functions according to different political perspectives (sometimes in compliance with different regulations). It is therefore essential to combine tasks and expertise between different government organisations and merge their practices using a variety of approaches. Moreover, the microfinance sector (specifically, microcredit) is regulated by different national regulatory frameworks, in particular by legislation on the provision of credit, consumer protection law and tax legislation. ${ }^{36}$ The legislation of the member states on different compartments of microfinance and microcredit may therefore greatly impact the activation and management process of microfinance programmes.

In order to implement and manage a successful microfinance programme, the managing authority needs to possess global expertise: political, technical, legal skills and assessment of potential areas of risk. With the aims of aligning all actors, implementing an integrated initiative ${ }^{37}$ and combining all the skills needed, most countries decided to create a steering committee or task force entrusted with the task of setting up the fund. This committee connects the interested parties to a central level (within a ministry or a plurality of ministries) and other actors involved. Such a practice proved effective in rationalising the process under several aspects; in fact, it allowed concentrating a variety of functions in one single entity and facilitated policy implementation. ${ }^{38}$

Once the decision on the creation of the fund has been made and the main actors have been involved, the next stage should consist in the preparation of a business plan, which must include a financial plan (EU financing and national and/or regional co-financing), the interested parties, activities to be carried out, processes, quality and quantity objectives and indicators of the microcredit fund, such as provision of credit, beneficiaries (e.g., ESF's priority groups), loan terms and conditions and exit plans. The financial engineering instruments funded by structural funds can be set up both as independent legal entities, governed by agreements between co-financing partners or shareholders, or as a 
separate block of finance within a financial institution. Once they have been established in both forms, they are regulated by specific regulations and other applicable documents and operate in accordance with the industrial plan or a specific document agreed upon with the managing authority or the holding fund. ${ }^{39}$ Terms and conditions for the operational programme contributions to the financial engineering instruments are set out in a funding agreement, which must be signed by the authorised representative of the financial instrument and the member state or the managing authority. As a part of the decision-making process, the latter should evaluate whether to implement the financial engineering action through a holding fund or direct contributions from the operational programme to the financial engineering instrument.

The fund holder or managing entity shall manage the funds provided by the ESF and the ERDF. This subject may consist of a public, regional, national or European financial intermediary. Theoretically, all public financial intermediaries may become fund operators, including those organisations already involved in the management of ERDF or ESF instruments.

As part of the decision-making process, the member states or managing authorities shall evaluate whether to implement the financial engineering operations through public contracts, in compliance with the legislation on public procurements, or through direct contributions. In general, the managing authorities organise a tendering procedure for the appointment of fund managers. However, regional or national organisations, such as development banks with fund managing expertise, may be designated as fund managers without the need for contract award procedures. In this case, regulatory or administrative provisions compatible with the EU treaty shall be applied in order to confer to the entity at issue exclusive management rights on the fund for the operations included in the programming period 2007-2013. ${ }^{40}$

The provision of direct contributions to experienced in-house managers has different advantages:

- Efficiency: lower control and administrative costs during programme selection and management phase.

- Reliability: a regional/national entity ensures compliance with the objectives of regional/national planning, transparent information flows and immediate controls.

In the event that a regional or national entity is chosen, the latter should have proven financial management expertise and skills (related 
to projects co-financed by the EU), sound knowledge of legislation and procedures, commitment to supporting regional development objectives and a strong result-oriented policy. State members or the managing authorities may also decide to implement the programme by awarding a contract directly to the European Investment Bank or the European Investment Fund, thanks to their particular legal status of EU organisations created under the EU treaty. Another option is to rely on institutions which collaborate as fund co-managers, such as regional financial institutions willing to use the EIF contributions. ${ }^{41}$

Once selected, the member state or the managing authority shall sign a funding agreement with the fund manager/operator. These contracts must ensure correct implementation of the strategy-including objectives, areas of intervention and final recipients/beneficiaries to be supported according to the operational programme - through a consistent investment plan, products and expected objectives to be achieved through the financial engineering instruments. The funding agreements should also include a performance-based remuneration system for the fund managers. Moreover, the funding agreements must include a set of regulations, covenants and procedures that must be followed by all interested parties with regard to the financial support granted by the operational programme. ${ }^{42}$ The financial intermediaries can be chosen by way of either public procurement or direct appointment by fund managers. Their choice should be based on the political-legal framework and the specific requirements of the microcredit/microfinance programmes to be implemented.

The design of a microfinance programme involves also additional phases than those above described (creation of partnerships, implementation of specific products, communication and marketing, risk management, compliance with the code of conduct, etc.), which are all essential for its success. In the future, one of the main challenges for microfinance programmes lies in achieving self-sustainability and independence from public aid. ESF contributions, in fact, offer the opportunity to strengthen the capacity of the financial intermediaries to test, adapt and standardise credit procedures so as to gain a greater degree of independence in the future.

\subsubsection{Some examples in Europe}

No doubt, the financing of microfinance programmes represents a critical issue. Financial sustainability is hard to achieve, especially for those microfinance organisations in Europe working with beneficiaries who are excluded from the traditional banking system. 
In France, the organisation France Initiative used the ERDF Regional Funds to fund equity and management costs of its own finance platforms. ${ }^{43}$ France Initiative is a network of associations offering honour loans (guarantee-free and interest-free loans), which currently coordinates 230 platforms. ${ }^{44}$ Active since 1985, it supported over 17,000 start-ups, creating or maintaining over 37,000 jobs. It generated a volume of $€ 166$ million of honour loans with a repayment rate of 98 per cent. ${ }^{45}$ The loans' average amount is $€ 8,150$, and they are destined for unemployed individuals, young people and women. The enterprises supported have an average of 2.2 employees each. Resources are provided by local government authorities, banks and companies, customers, public entities and international funds. In 2011, €315 million dedicated to credit were financed by the regional councils (22.7 per cent), the European Funds (ERDF and LEADER+; ${ }^{46} 7.2$ per cent) and savings and loans banks, companies and other private contributors. Besides financing the honour loans, the European Funds provided financial support to business support services for entrepreneurs, in particular during the start-up phase of companies, with a 7 per cent share of the total budget. ${ }^{47}$

In England and Scotland, the ERDF and ESF made possible the creation of several funds providing loans to microenterprises, including groups of particularly vulnerable individuals. For instance, Principe Scottish Youth Trust Business PSYBT used the ERDF funds for the implementation of its combined "credit and grant" programme dedicated to young entrepreneurs in need of financial inclusion. ${ }^{48}$

Likewise, the First Enterprise Business Agency was received funds from the ERDF to support its activities supporting immigrant entrepreneurs and ethnic minorities. ${ }^{49}$

In Finland, the ERDF supports investments by Finnvera; specifically, investments in working capital, loans to enterprises, microcredit, loans to female entrepreneurs and other credit with environmental purposes. Moreover, Finnvera provides ERDF-backed guarantees. ${ }^{50}$

In Portugal, ERDF and ESF were used to create a fund for microenterprises by a network of commercial banks that cover the entire national territory (RIME project, budget allocation: $€ 20$ million). Established 1995, RIME aimed to develop local entrepreneurship potential, promote the creation of jobs and tackle adverse economic conditions. RIME provided important contributions to investments and the creation of jobs as well as low-interest loans to microenterprises (crafts, local services and rural tourism), in particular those created by young entrepreneurs in densely 
Table 2.2 Use of ERDF and ESF for microfinance programmes

\begin{tabular}{|c|c|c|}
\hline Country & Fund & Use \\
\hline France & ERDF & to finance honour loan platforms \\
\hline United Kingdom & ERDF and ESF & $\begin{array}{l}\text { funds to youth, immigrants and ethnic } \\
\text { minorities }\end{array}$ \\
\hline Finland & ERDF & investments in Finnvera \\
\hline Portugal & ERDF and ESF & RIME project, loans for microenterprises \\
\hline
\end{tabular}

Source: Authors' elaboration.

populated areas. Between 1994 and 1999, 18,479 jobs were created, of which 9,919 benefit women. ${ }^{51}$ However, in the most critical regions, such as the Lima Valley (North Region), the programme saw a very low number of applicants. This was due to a lack of local infrastructure, red tape, low education of the potential beneficiaries and poor information on the support services for the submission of the applications. ${ }^{52}$

\section{Notes}

1. Although this chapter was prepared jointly by the authors, Sections 2.1 and 2.2 were written by Giorgio Centurelli, while Section 2.3 and 2.5 was written by Pasqualina Porretta and Section 2.4 was written by Fabrizio Santoboni.

2. EU (1992), Treaty of Maastricht on European Union, https://www.ecb.europa. eu/ecb/legal/pdf/maastricht_en.pdf.

3. European Commission (2004), Annex of the commission regulation (EC) no. 448/2004 of 10 March 2004 - Rule no. 8: Venture capital and loan funds and Rule no. 9: Guarantee funds, http://ec.europa.eu/regional_policy/sources/ docoffic/official/regulation/content/en/02_pdf/00_9_4_expend2_en.pdf.

4. European Commission (2000), Commission regulation laying down detailed rules for the implementation of council regulation (EC) no. 1260/1999 as regards eligibility of expenditure of operations co-financed by the structural funds, Official Journal of the European Communities, http://ec.europa.eu/ regional_policy/sources/docoffic/official/regulation/pdf/reg_elig_en.pdf.

5. European Commission (1999), Council regulation laying down general provisions on the structural funds, Official Journal of the European Communities, http://eur-lex.europa.eu/legal-content/EN/TXT/PDF/?uri=CELEX:31999R126 0\&rid $=5$.

6. European Commission (2004), Commission regulation amending regulation (EC) no. 1685/2000 laying down detailed rules for the implementation of council regulation (EC) no. 1260/1999 as regards the eligibility of expenditure of operations co-financed by the structural funds and withdrawing regulation (EC) no. 1145/2003, Official Journal of the European Communities, http:// eur-lex.europa.eu/legal-content/EN/TXT/PDF/?uri=CELEX:32004R0448\& rid $=4$. 
7. European Commission (2004), Commission regulation amending regulation (EC) no. 1685/2000 laying down detailed rules for the implementation of council regulation (EC) no. 1260/1999 as regards the eligibility of expenditure of operations co-financed by the structural funds and withdrawing regulation (EC) no. 1145/2003, Official Journal of the European Communities, http://eur-lex.europa.eu/legal-content/EN/TXT/PDF/?uri=CELEX:32004R04 48\&rid=4 - Rule no. 9 - 1 General rule.

8. European Commission (2004), Setting out rules for the implementation of council regulation (EC) no. 1083/2006 laying down general provisions on the European Regional Development Fund, the European Social Fund and the Cohesion Fund and of regulation (EC) no. 1080/2006 of the European Parliament and of the Council on the European Regional Development Fund, http://eur-lex.europa.eu/legal-content/EN/TXT/PDF/?uri=CELEX:320 06R1828\&from=IT.

9. Councilregulation(EC)(2006), LayingdowngeneralprovisionsontheEuropean Regional Development Fund, the European Social Fund and the Cohesion Fund and repealing regulation (EC) no. 1260/1999, http://eur-lex.europa.eu/ legal-content/EN/TXT/PDF/?uri=CELEX:02006R1083-20131221\&rid=1.

10. European Parliament and Council (2006), On the European Regional Development Fund and repealing regulation (EC) no. 1783/1999, http:// eur-lex.europa.eu/legal-content/EN/TXT/PDF/?uri=CELEX:02006R1080-201 $00618 \&$ qid $=1404848626582 \&$ from $=\mathrm{EN}$.

11. http://eur-lex.europa.eu/legal-content/EN/TXT/PDF/?uri=CELEX:32006R10 $81 \&$ from $=$ IT.

12. As part of free competition within the EU domestic market and, specifically, in light of public services opened up to competition from the private and voluntary sector, member states sometimes intervene by using their own resources to support certain businesses or protect some of their domestic sectors. By supporting some companies to the detriment of the competitors, state aid can distort competition. State aid is prohibited by the treaty on the Functioning of the European Union. Yet a number of exceptions exist and authorise those aid measures justified by the need of protecting objectives of common interest, i.e., aid directed to services of general economic interest, provided that they do not distort the competition to an extent contrary to the common interest.

13. European Commission (2014), Fact sheets, Financial Instruments in Cohesion Policy 2014-2020, http://ec.europa.eu/regional_policy/sources/docgener/ informat/2014/financial_instruments_en.pdf.

14. European Commission (2011), Communication from the commission to the European Parliament and the Council: a framework for the next generation of innovative financial instruments - the EU equity and debt platforms, $\operatorname{COM}(2011), 662$ final of 19.10.2011, 19, http://ec.europa.eu/economy_ finance/financial_operations/investment/europe_2020/documents/ com2011_662_en.pdf.

15. European Parliament and Council (2011), Amending council regulation (EC) no. 1083/2006 as regards repayable assistance, financial engineering and certain provisions related to the statement of expenditures, http://eur-lex. europa.eu/LexUriServ/LexUriServ.do?uri=OJ:L:2011:337:0001:0004:EN:PDF.

16. Ibid. 
17. Communication from the commission to the European Parliament and the Council. A framework for the next generation of innovative financial instruments: the EU equity and debt platforms - Final COM (2011) 662 of 19.10.2011, http://ec.europa.eu/economy_finance/financial_operations/investment/ europe_2020/documents/com2011_662_en.pdf.

18. European Parliament and Council (2013) laying down common provisions on the European Regional Development Fund, the European Social Fund, the Cohesion Fund, the European Agricultural Fund for Rural Development and the European Maritime and Fisheries Fund and laying down general provisions on the European Regional Development Fund, the European Social Fund, the Cohesion Fund and the European Maritime and Fisheries Fund and repealing council regulation (EC) no. 1083/2006, http://eur-lex.europa. eu/LexUriServ/LexUriServ.do?uri=OJ:L:2013:347:0320:0469:EN:PDF.

19. European Commission (2014), Financial instruments in ESIF programmes 2014-2020: a short reference guide for managing authorities, http:// ec.europa.eu/regional_policy/thefunds/fin_inst/pdf/fI_esif_2014_2020.pdf.

20. EU (2009), "The control system for Cohesion Policy. How it works in the 2007-13 budget period", http://ec.europa.eu/regional_policy/sources/ docgener/presenta/audit2009/audit2009_en.pdf.

21. Ibid.

22. Ibid.

23. Ibid.

24. Ibid.

25. Ibid.

26. Ibid.

27. Ibid.

28. The discussion on the discharge is based on the annual report of the EU Court of Auditors as well as the EC special reports and opinions.

29. Ibid.

30. Typical irregularities are lack of supporting documents (e.g., time records of staff, invoices or overhead allocation keys) that should be kept for the purposes of the audit trail, to facilitate controls, non-deduction of revenue from project expenditure, inclusion of ineligible expenditure such as recoverable VAT and breaches of tendering requirements.

31. Brigitte Maas and Stefanie Lämmermann (2012), "Designing microfinance operations in the EU. A manual on how to build and implement microfinance support programmes using the ESF", http://www.microfinancegateway.org/ sites/default/files/mfg-en-toolkit-designing-microfinance-operations-in-theeu-a-manual-on-how-to-build-and-implement-microfinance-support-programmes-using-the-esf-2013.pdf.

32. The NAP for social inclusion is an instrument which, every two years, "provides the creation and development of a strategic plan to tackle any form of social exclusion and marginalisation at EU level".

33. Brigitte Maas and Stefanie Lämmermann (2012), "Designing microfinance operations in the EU. A manual on how to build and implement microfinance support programmes using the ESF", http://www.microfinancegateway.org/ sites/default/files/mfg-en-toolkit-designing-microfinance-operations-in-theeu-a-manual-on-how-to-build-and-implement-microfinance-support-programmes-using-the-esf-2013.pdf. 
34. "The 2012 National Reform Programme (NRP) represents the main component of the 'European Semester', the annual cycle dedicated to the coordination of the economic and budget policies, and constitutes a key moment in the coordination between EU policies and national policies. The NRP aims to provide an overview on the reforms implemented following the recommendations adopted by the EU for the previous year, illustrating their scope, compliance with the European Union guidelines and their expected impact. Moreover, the NRP presents an agenda of interventions planned for the months ahead, to define the action plan through which Italy intends to achieve the objectives defined at European level", http://www.politicheeuropee.it.

35. ESF, Priority axis 3 on social inclusion.

36. Leone P. and Porretta P. (2014), "Microcredit guarantee funds in the Mediterranean. A comparative analysis", Palgrave Studies in Impact Finance, Palgrave Macmillan.

37. In Italy, for example, several actors were involved by the Lombardy Regional Administration in the implementation of the microfinance fund through JEREMIE, directed at strengthening the cooperative sector. Besides the ESF managing authority, the following actors were involved: Finlombarda (the regional financial entity entrusted with fund management), other regional directorates with responsibilities and functions in the cooperative system (DG for Family and Social Solidarity and DG for Enterprises and Industry, Crafts, Housing and Cooperation), the financial intermediaries, the cooperatives and the Ministry of Labour. All these organisations (apart from the ministry) were involved in a series of informal meetings to verify the economic and administrative feasibility of the project. Following the start-up phase, a steering committee was created to monitor the correct and effective management of the programme.

38. Brigitte Maas and Stefanie Lämmermann (2012), "Designing microfinance operations in the EU. A manual on how to build and implement microfinance support programmes using the ESF", http://www.microfinancegateway.org/ sites/default/files/mfg-en-toolkit-designing-microfinance-operations-in-theeu-a-manual-on-how-to-build-and-implement-microfinance-support-programmes-using-the-esf-2013.pdf.

39. COCOF_10-0014-04-EN.

40. Directive no. 2004/18/EC, art. 18.

41. http://www.eif.org/what_we_do/jeremie/faq/index.htm\#What\%20is\%20 the $\% 20$ role $\% 20$ of $\% 20$ a\%20Fund $\% 20$ Holder.

42. COCOF_10-0014-04-EN.

43. EMN (2009), "COPIE 2 Access to Finance Baseline Study", http://www. emnconference.org/archives/news_summer-2009_en.html\#paragraphe14.

44. http://www.initiative-france.fr/.

45. http://www.european-microfinance.org.

46. Liaison entre actions de développement de l'économie rurale (link between actions to develop the real economy), supports locally designed rural development projects aimed at revitalising the territory and the creation of jobs. In other words, its objective is to promote "an integrated, endogenous and sustainable development of rural areas". 
47. France Initiative (2012), "Rapport annuel 2011", http://www.banque-france. fr/fileadmin/user_upload/banque_de_france/publications/Rapport-annuel2011-Observatoire-de-la-Micro-finance.pdf.

48. EMN (2009), "COPIE 2 Access to Finance Baseline Study", http://www. emnconference.org/archives/news_summer-2009_en.html\#paragraphe14.

49. Ibid.

50. Ibid.

51. http://www.europarl.europa.eu/meetdocs/committees/rett/ 20010619/439210EN.pdf.

52. INAISE (1997), "Financial instruments of the social economy (FISE) in Europe and their impact on job creation", and M. N. O. Roca (2000), "Financial instruments of the social economy (FISE) in Europe and their impact on job creation".

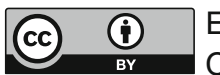

Except where otherwise noted, this work is licensed under a Creative Commons Attribution 3.0 Unported License. To view a copy of this license, visit http://creativecommons.org/licenses/by/3.0/ 